\title{
Determinants of Agricultural Export in Sub- Saharan Africa: Evidence from Panel Study
}

\section{Eyayu Tesfaye}

Senior Lecturer, College of Business and Economics, Department of Economics, Addis Ababa University, Addis Ababa, Ethiopia

E-mail for correspondence: tesfaye.mulu@gmail.com

Cell Phone: +251913034147

Received: Aug 4, 2014;

Accepted: Aug 22, 2014;

Published: Aug 30, 2014

Source of Support: Nil

Conflict of Interest: None Declared

\begin{abstract}
Despite the critical importance of agriculture in SSA countries; there are constraints behind, between, and beyond the border that directly and indirectly affects agricultural export performance of these countries. This paper attempts to explain theoretically and assess empirically the demand and the supply side factors affecting agricultural export of SSA countries. Specifically, the study focuses on analyzing the relative importance of the two major factors in determining the countries agricultural export performance. Panel data set with fixed effects estimation technique is used to address the question. The data set covers 47 SSA countries over the periods 2000-2008. The estimation result shows that on the supply side, factors such as real GDP, real GDP (lagged) of exporting country and lagged agricultural input use positively and significantly affects agricultural export of the SSA countries. The study also indicates that on the demand side the effect of per capita GDP of US, the major trading partner of SSA countries, is positive and significant. Moreover, the effect of US import tariff imposed on agricultural products from SSA countries is negative and significant. Therefore, the overall result reiterates that both supply side and demand side factors are equally important in determining agricultural export performance of SSA countries.
\end{abstract}

Keywords: Agricultural export performance, demand side factors, supply side factors, fixed effects estimation

\section{INTRODUCTION}

It is not difficult to find statements lamenting Africa's purportedly poor export performance. For example, the recent Commission for Africa study suggests that:

"....The last three decades has seen stagnation in Africa. The composition of Africa's exports has essentially remained unchanged, and has contributed to a collapse in Africa's share of world trade...Africa will not be able to achieve the Millennium Development Goals, nor set itself on a sustainable path to growth and poverty reduction, without increased trade." Commission for Africa (2005), as cited in Prizzon and Mold (2010), pp: 2.

The United Nation Millennium Development Goals of reducing poverty by half, between 1990 and 2015, the proportion of people whose income is less than one dollar a day has energized the school of thought calling for Africa to redefine the importance of agricultural development. Wood (2002) argues that because it is land abundant, Africa will always have larger primary sector and smaller manufacturing sector than the land scarce regions of Asia and Europe.
According to Cleaver (1985) agriculture is important in SSA contributing from $20 \%-60 \%$ of GDP depending on the country; an average of $80 \%$ employment and $50-90 \%$ of export. Much of the industry and trade depends on agriculture.

The importance of agriculture in SSA has not been stressed enough given that it is central to economic growth and most of the economic activities depend on it. Africa's exports remain dominated by primary commodities, and the share of agriculture in SSA's total exports has declined sharply in the last 40 years. Only a few SSA countries have achieved significant diversification of their exports. Despite those trends, agriculture remains the main export-revenue source for many SSA countries and the largest income generator for their population (WB, 2007).

The region's share of global agricultural export has declined gradually from almost $10 \%$ four decades ago to around 3\% today. On the import side, the opposite pattern emerges as Sub -Saharan Africa is the only developing-country region that has seen its share of world agricultural imports increase rather than decrease (Baccetta, 2007; WB, 2007; and Christiansen, 2005). 
The cause of poor export performance in agricultural sector in SSA has been attributed to poor domestic policies as well as restrictive policies by developed countries. Furthermore, the ability of the region to increase exports (its export supply response) is constrained by structural rigidities in production capacity, infrastructure and institutional barriers to trade costs) followed by overvalued exchange rate and anti agricultural industrial policies (Biggs, 2007; Kandiero and Randa; 2004; Alemayehu, 1999).

Agricultural markets are among the most heavily distorted in the world. The agricultural protection applied by industrial countries to SSA exports is higher than applied to other developing countries (Kandiero and Randa; 2004).

According to IMF and WB (2002) if greater market access is granted by industrial countries to Africa's product, real incomes in SSA would increase by USD 6 per person and reduces the number of people living in poverty by as much as $13 \%$ by the year 2015. Moreover, Ghura and Grennes (1994) as cited in Daniel et.al (2002) found that the impact of $1 \%$ increase in OECD real income growth results in primary export demanded by $1.6 \%$ implying that a world recession has potential to disrupt economic growth, thus lowering economic growth in SSA.

SSA'S share in the European markets has declined despite nearly three decades of trade preference extended to SSA under several ACP-EC agreements and response of SSA's agricultural exports to AGOA's commercial incentives were not significantly different from zero(Bedassa and Bichaka ,2007).

Agriculture is partly dependent on imported inputs, fertilizers, pesticides, equipments. Balance of payment crisis have caused reduced imports of inputs and equipment, perhaps causing a reduction in agricultural production and export of SSA (Cleaver1985).Moreover, the high susceptibility of most African economies to trade and current account deficit arises from world share, declining terms of trade, excessive export turning volatility and falling export revenues are reasons for poor export performance of the region in general and SSA's in particular( Ignacio, 2007; and Ackah and Morrrissey,2005).

So far, there has been a divergence of opinions as to what really undermines Africa's exports in global trade. While a school of thought believes that it is the trade restrictions that hindered Africa's exports to developed countries and some developing countries, thereby reducing the income level and employment rate, another argued that even if Africa's exports are allowed free access to the developed countries' markets, the continent lacks the ability to produce to meet the demand due to Africa's supply constraints (Kareem, 2009).

Identifying and assessing the major constraints that significantly determines the overall agricultural export performance in SSA will give some useful guidance to policy makers in designing sound macroeconomic policies to improve the sectors' export performance and can be used as a base for detailed study on individual country agricultural export constraints to take remedial measures and ultimately to achieve overall economic growth.

The main objective of this paper is to explain theoretically and assess empirically both the demand and supply side factors affecting SSA countries agricultural export. Specifically, the study attempts to investigate the relative importance of the two major factors in determining the countries agricultural export performance.

The study uses an econometric model of panel data regression with fixed effects estimation technique as a method of data analysis. The cross sectional time series data set of 47 SSA countries over the period 2000-2008 is used to address the above issues. The methodology relates the dependent variable, total agricultural export (in million USD), with the selected supply and demand side explanatory variables. The structure of the paper is as follows: Section two is devoted to related literatures regarding the subject. In section three, model specification, estimation results and discussion were presented. The last section contains concluding remarks.

\section{LITERATURE REVIEW}

\section{OVERVIEW OF IMPORTANCE OF AGRICULTURE IN SSA}

Based on the trade theory of comparative advantage, Africa continues to produce and export its raw materials or primary goods, where it is said to have the comparative advantage. But the comparative advantage theory is has been disappointing as African countries have been forced into the role of exporting raw material and other primary commodities with little or no development impact. Most of Sub-Saharan African countries depend almost on primary commodities for their foreign exchange earnings. African merchandise exports did not rise significantly for the period 1980 to 2006 particularly when South Africa and Nigeria are not included (Amin et al, 2007).

Capitalizing upon agriculture's potential to drive development in Sub-Saharan Africa (SSA) is both critically important and urgent for enhancing aggregate economic growth and improving the welfare of hundreds of millions of extremely poor people. Agriculture employs $62 \%$ of the population of SSA (excluding South Africa) and generates $27 \%$ of GDP of these countries, with the majority of the poor living in rural areas (FAO, 2006; World Bank; 2006b as cited in Staatz and Dembélé, 2007). More than 215 million people, nearly a third of the population, are malnourished, and almost half live on less than a dollar a day. SSA is the only region of the world where poverty is still strongly a rural phenomenon - and undernourishment have been increasing over the past 20 years and where those living on less than $\$ 1 /$ day have become poorer. This weak economic performance is closely linked to slow productivity growth in the agricultural sector, as the agricultural sector is the key determinant of overall economic growth (World Bank, 2005c as cited Staatz and Dembélé, 2007). 
The performance of the sector over the last three decades suggests that the sector has not been able to serve its potential role as engine of growth in the sub-region. Rather than stimulating economic growth, the agricultural sector had dragged it down in many African countries (Oyejide et.al, 2000). A close look at agricultural production and exports trends explains this conclusion. Put simply, various indices of agricultural production and exports revealed downward trends, until fairly recently. Over the past 30-40 years SSA's share in worlds export has been declining and along with it the standard of living of most Africans .This outcome is the result of combination several factors: the structure of international trade; the composition of international trade; the composition of SSA trade; low productivity as a result of poor governance ; poor trade and economic policies applied by SSA countries over the past 20 years ; poor infrastructure in SSA countrieswhich is related to the high cost of doing the business in SSA; the decline in demand for key export produced by SSA ; the substantial erosion of market share of SSA countries; market access and constraint; and agricultural policies in developed countries. At the same time, more than any other developing region, SSA remains heavily dependent on export of primary commodities -some of whose price have been steadily decline (Cleaver and Donovan, 1995; Maunduna, 2005).

The dismal trend in the agricultural export of SSA has been attributed to poor domestic policies and capacity constraints (supply side/internal factors)as well as restrictive policies in developed countries (demand side Factor) (Bacchetta,2007; Redding and Venables,2003; Kandiero and Randa, 2004; Love and Turner,2001).

\section{SUPPLY SIDE FACTORS AFFECTING AGRICULTURAL} EXPORT IN SSA

The ability of a country to increase exports (its export supply response) is constrained by structural rigidities in production capacity. Macro environment; poor infrastructure; access to inputs (like fertilizer and credit to increase production); access to information about the market price, standards; and structural and quality of institutional arrangements and excessive tax on agriculture are among the major supply side constraints that hinder agricultural export of SSA. (Ackah and Morrissey, 2005).

Supply conditions are fundamental in defining the export potential of the economy and, for a given level of access to international markets, countries with better supply conditions are expected to export more (Kandiero and Randa; 2004; Taylor 2007).Moreover, Fugazza (2004) as cited in Beshir (2010) analyzed the major determinants of export performance in 84 countries by employing an econometric model of bilateral trade flows using gravity techniques. The result shows that, while trade barrier continue to be concern, supply-side conditions have often been the most important constraint on export performance in various regions particularly in Africa, despite generalized deepening of international trade integration.
According to Schiff and Valdes(1992) as cited in Kandiero and Randa (2004) among all developing country regions SSA countries imposed the highest level of taxation (both implicit and explicit) on agriculture ranging from 46-59 percent. The direct tax on agriculture in these countries is similar to the implicit tax resulting from industrial countries protection and macroeconomic policies. Herman (1997) did similar study that focused on individual crops and found significant policy biases against agriculture, which were more excessive for export crops such as coffee than food crops. The removal of subsidies in recent years has caused prices to increase, reducing fertilizer usage among many small farmers. In some SSA countries, the imposition of import control on fertilizer resulted in higher prices of fertilizers have led many farmers to sharply reduce the amount of fertilizer usage in production in an effort to cut costs. The median SSA fertilizer usage is below the global median $(26.6 \mathrm{~kg}$ per hectare) (Kandiero and Randa, 2004).

Wang and Winters (1998) as cited in Frazer and Biesebroeck (2007) in summarizing a set of World Bank technical papers finds that "the evidence suggests that it is African countries' own trade policies and not those of their partners that must be changed in order to promote growth. Infrastructure and trade facilitation services problems abound in low-income countries and the high costs and deficient service flows from these non-tradable factors of production often cause serious problems for export competitiveness. Trade requires official paperwork, transport, port handling, and customs inspections, and the high costs, excessive documentation and procedures, and time delays involved in these services have been shown to be one of the most critical impediments to export growth and diversification in many countries (Sachs and Warner, 1995 as cited in Biggs, 2007).

According to Mbekeani (2007) weak infrastructure is a major impediment to trade, competitiveness and sustainable development in most SSA countries, particularly land-locked and small island countries.

Limão and Venables (2000) finds that the relatively low level of African trade flows "is largely due to poor infrastructure. The researchers also reiterated a significant impact of transport costs on trade, finding that the median landlocked country has only 30 percent of the trade volume of the median coastal economy and that improving the standard of infrastructure of the most badly affected countries stands to have a large expansionary effect on their trade. An empirical study by Babatunde (2009) reveals that being land locked country in SSA can adversely affect the performance of merchandise export. Kym (1999) as cited in Kandiero and Randa (2004) argue that poor infrastructure has a negative impact on rural prosperity as it affects fertilizer and other in the put uses, raises producer price elasticity and hinders market integration.

The other major factor that affects export supply is real exchange rate. Agbeyegba et al. (2004) argue that overvaluation of exchange rate has a direct effect by suppressing import and export bases measured in 
domestic currency terms. Fugazzza (2004) empirically analyze the effect of real depreciation on export performance by taking sample SSA countries with in the period 1988-1999 and proves that for all periods on average a 1 percent real exchange rate depreciation could increase export by 6 to 10 percent. In low income countries undervaluation or overvaluation) of the currency can bolster or undermine export competitiveness. Love and Turner (2001) also empirically investigates the impact of real exchange rate policy on export in SSA by using panel data methodology over the period 1975-1995 and real exchange rate as a measure of international competitiveness and concludes that appreciation of real exchange rate has detrimental effect on export performance of the region.

A study by Were et al (2002) as cited in Beshir (2010) examine the determinants of Kenya's export volume by disaggregating total export of goods and services in to two categories: traditional agricultural exports (tea and coffee) and other export of goods and services using an error correction model and found that supply response for real exchange rate depreciation is significant.

Institutional quality is another major supply side constraint for agricultural export of the region. The impact of institutional quality on export of primary commodities is likely differing from its effect on manufactured exports. Endowment of natural resources may create natural rents that are usually controlled by administration and generate corrupt competition over their distribution as Ades and di Tella (1999) as cited in Meon and Sekkat,(2006) suggests. In such context, export of primary products may be positively rather than negatively associated with lack of institutional quality.

Apart from the direct effect, institutions may also indirectly affect trade through their impact on other variables that determine trade flows like investment and productivity (Méon and Sekkat, 2006).

According to Carmingani and Chowdhury (2007) the key to the SSA specific curse appears to lie in the interaction between institutions and primary commodities (i.e. institutional constraints in the region were found to be the major constraining factors for poor performance of export of primary commodities). Foreign Direct Investment(FDI) can play a significant role in promoting economic development in low-income countries by serving as a mechanism through which superior technology and managerial know-how are transferred to such countries and to facilitate exporting activities generated by the FDI flows( Oyejide and Ademola,2007).

A study by Staatz and Dembélé (2007) indicates that agriculture's capacity to contribute to growth and poverty alleviation in Africa has been greatly constrained in the past by underinvestment and miss-investment, in both physical and human capital, resulting in a huge cost to Africans in terms of foregone well-being.

Helleiner's (2002) as cited in Bacchetta (2007) also found that FDI has not as yet made a particularly important contribution to African non-traditional export expansion.
Oyejide (2007) investigated the critical of African investment codes which place heavy reliance on fiscal and other incentives which may be largely ineffective in attracting FDI and are at the same time quite costly in terms of lost revenue.

Apart from the above supply side factors the size of importing and exporting countries and degree of openness of the countries determines the export of primary commodities. Babatunde (2009) empirically investigates the effect of productive capacity (proxy by GDP of SSA countries) on its export by using both random and fixed effect regression of export supply model. The result reveals that GDP has highly significant positive impact on export volumes and export volumes appear to be lower when manufacturing share in GDP is higher.

Traditionally, economists have argued that more open economies grow faster. This idea was largely based on the argument that openness improves resource allocation. According to Rodrik (1997) high levels of trade restrictions have been an important obstacle to exports, and their reduction can be expected to result in significantly.

\section{DEMAND SIDE FACTORS AFFECTING AGRICULTURAL} EXPORT IN SSA

On the demand side anti export biases against the commodities of SSA countries in terms of tariff, non tariff and technical barriers determines the degree of market access and hence volume of export in region.

According to Biggs (2007) the world trading system has become more development-friendly in the 1990s, but it is still unwelcoming to the exports of low-income countries. Tariffs and quota arrangements of developed countries especially for agricultural products undermine incentives in low-income countries to move in to higher productivity, nontraditional export.

Paiva (2008) empirically analyses the effect of demand side policies on export of agricultural products of SSA by using the data set that covers bilateral trade in agricultural goods for 152 countries over the periods19901993 and 1999-2002.The estimation support claims that protectionism and distortive subsidies to agriculture remain widespread among industrialized nations.

Tokarik (2005) has assessed the impact of removing agricultural support from OECD using both partial and general equilibrium analysis. In the partial equilibrium analysis the study shows the impact of removing two types of supports; market price support and complete liberalization. As it is expected the removal of support results in the increase in international prices of commodities. Despite most-favored nation (MFN) status and in some instances preferential tariffs, many products of trade interest to African countries continue to be subject to tariffs in excess of 100 percent in developed countries. Kandiero and Randa (2004) find that agricultural support to OECD farmers and standards and technical barriers have a statistically significant negative impact on SSA agricultural export share. 
Wilson and Otsuki (2004) as cited in Ignacio (2007) examine the impact of standards and technical regulations on a firm's export. The finding reveals that varying standards across different markets cause diseconomies of scale and reduce the likelihood of firms entering more than three markets.

Apart from then non tariff barriers imposed by OECD countries, the tariff barriers levied by major trading partners of SSA region such as EU, USA, Japan and China on agricultural exports hinders the move towards achieving better export performance (Kareem, 2009). A study undertaken by IMF and WB (2001) revealed that tariff peaks and escalation in sensitive products (textiles and clothing, agriculture, food products, wood products, and pulp and paper) disproportionately affect the products exported by developing countries and which inhibit the diversification of exports toward higher value-added products.

The exported commodities from the SSA countries fall under different market access programs: Most-Favored Nation (MFN), the Generalized System of Preferences (GSP); GSP for Least Developing Countries (GSP-LDC), and the AGOA program. Romalis(2003) as cited in Frazer and Biesebroeck (2007) found that GDP growth rate and trade volume of countries most affected by the establishment of the GSP increased significantly.

AGOA provides preferential access to U.S. markets for eligible products from designated countries of Sub-Saharan Africa (SSA) as well as improved access to U.S. credit and technical expertise. Gbadebo (2007) as cited in Beshir (2010) modeled Africa's agricultural exports to the United States. In doing so, he used a dynamic econometric model-Vector autoregressive Analysis- which helps to look at both the short-run and long- run effects of income and price changes. The overall result for the estimated demand functions for agricultural commodities covered by the study suggests that there is a statistically significant demand response to income changes in the US.

\section{Model Specification, Estimation Results and DISCUSSION}

\section{MODEL SPECIFICATION}

Some of the studies (Mold \&Morrissey,2006) on the determinants of export performance in SSA assumes that exports are determined by supply side variables, such as domestic prices (official or market determined), the growth of GDP, index of variable cost and capacity utilization, fewer studies have focused on the demand side constraints of exports in SSA, such as income and prices in competitor countries.This gap in literature seems to have arisen because the typical developing country is assumed to be small and face an infinitely elastic demand for its exports, so that changes in foreign demand can influence exports only through changes in world prices.

Furthermore, the study have ignored the role of other supply side factors such as natural barriers and institutions, domestic infrastructure, exchange rate overvaluation in explaining SSA export performance .Ignoring such factors and other supply and demand factors yield inconclusive results.

A study by Babantude (2009) try to address issue by using a system of equations from the demand and supply side determinants of exports in SSA, but this study also includes real income of importing country without considering other major demand side constraints and policy variables .The supply side variables included in this study are statistically insignificant which indicates that factors external to SSA countries are the most important determinants of their major export commodities.

In modeling determinants of the value of total agricultural export in SSA, A study by Kandiero and Randa (2004) attempts to inculcate the supply and demand side factors but this study also overlooks some of the variables that can significantly affect the volume of trade flow between SSA and its major trading partners. I then extended the model by including basic determinants of agricultural export in SSA to achieve in depth export analysis with the extensions. The extended or modified model includes explanatory variables which are overlooked in the model specified by Kandiero and Randa (2004).

Real GDP of the exporting country which shows the total potential supply capacity of the country; Per capital GDP of the major trading partners /importing countries to evaluate the effect of level of development/import demand of SSA major trading partners on agricultural export of the region; Institutional quality is incorporated to see the effect of institutional setup of a particular country in terms of trade freedom, property right, investment procedure, quality and control of corruption on the total agricultural export; Openness can give an indication of the degree to which an economy is open to trade; this variable is included in the model to capture the effect of country's trade integration with the ROW on total agricultural export; FDI in flow as percentage of GDP is included to analyze its effect on SSA's total agricultural export; and landlockedness dummy is also included in the extended model. This study uses panel data estimation, so that variations over both the cross section and time series dimensions are fully utilized. The general form of linear panel regression model is specified as:

$\mathrm{TAE}_{\mathrm{it}}=\alpha_{\mathrm{i}}+\beta \mathrm{X}_{i t^{\prime}}+\mathrm{u}_{i t} \quad \mathrm{i}=1,2, \ldots \ldots \ldots, \mathrm{N} \quad \mathrm{t}=1,2, \ldots \ldots \ldots, \mathrm{T}$.

Where, $\mathrm{u}_{i t}=\mu_{\mathrm{it}+\mathrm{vit}}$

The vector $\beta$ is a constant vector of parameters that is of primary interest; $i$ and $t$ denotes cross section units (countries in this study) and time period respectively. $\mu_{\mathrm{it}}$ denotes the unobservable individual specific effects which are time invariant and account for any individual-specific effects not included in $X$, vit is the usual error component which is assumed to be IID $\sim\left(0, \sigma^{2}\right)$ (Baltagi,2005).

$\mathrm{TAE}_{\mathrm{it}}$ represents Total Agricultural Export of SSA country $i$ at period $t$ (in million USD).

$X_{i t}$ represents a vector of (logs of) the following explanatory variables: 
RGDPE $_{\mathrm{it}}=$ Real GDP of the exporting countries at time $t$.

$\mathrm{GDPCAP}_{\mathrm{jt}}=\mathrm{GDP}$ Per Capita of major trading partners $\mathrm{j}$ (US and EU) at time $t$.

REER $_{i t}=$ Real Effective Exchange Rate of SSA countries at time $t$. INST $_{i t}=$ is an index of quality of SSA countries institution at time $t$ INFRA $_{\text {it }}=$ Internal Infrastructure of SSA countries at time $t$

$\mathrm{OPENN}_{\mathrm{it}}=$ Openness (measured by the ratio of Export plus Import to GDP) at time $\mathrm{t}$

$\mathrm{FDI}_{\mathrm{it}}=\mathrm{FDI}$ inflow as \%GDP to SSA countries at time $\mathrm{t}$

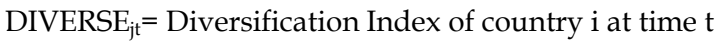

$\mathrm{FTP}_{\mathrm{jt}}=$ Trade policy Index of major trading partners, proxide by import tariff imposed on agricultural commodities from SSA by (US and EU) at time $t$.

INPUTS=refers to agricultural input use (proxide by fertilizer consumption per hectare of arable land)

LANDLOCK dummy= takes value 0 if the country is land locked 1 otherwise

\section{Model Estimation Results and Discussion}

After analyzing the various econometric issues that ought to be taken into consideration, the estimation technique which results in consistent and unbiased estimates is selected. In this study the fixed effects estimation technique is preferred as the estimation technique yield efficient and consistent results (ANNEX1).

Turning to the actual results in Table 1 of all supply side variables real GDP and real GDP (lagged) of exporting countries and lagged value of agricultural inputs do have positive and statistically significant coefficients. Agricultural export may not respond immediately and fully to changes real GDP and use of factor inputs. Therefore, a one year lag of these two variables is used in estimating the model to analyze their direct effect. When the variable, real GDP (lagged) of exporting countries, is included in the model it might be collinear with real GDP, but this may not be considered as a problem as long as it leads to reliable estimates with their expected sign.

Table 1: Regression Results under Fixed Effects Estimation Technique

Dependent Variable- Log of Total Agricultural Export, 2000-2008

\begin{tabular}{|c|c|c|c|}
\hline Independent Variables & Coefficient & t-ratio & p-value \\
\hline $\operatorname{Ln}\left(R G D P_{i t)}\right.$ & 1.358 & $3.56^{* *}$ & 0.001 \\
\hline $\operatorname{Ln}\left(R G D P_{i t_{-} 1}\right)$ & 0.046 & $3.52 * *$ & 0.001 \\
\hline $\operatorname{Ln}\left(G D P C A P U S_{j t}\right)$ & 2.796 & $2.02 * *$ & 0.049 \\
\hline Ln (FDIPERGDPit) & 0.013 & 0.47 & 0.641 \\
\hline $\operatorname{Ln}\left(R E E R_{i t}\right)$ & -0.014 & -0.60 & 0.554 \\
\hline $\operatorname{Ln}\left(O P E N_{i t}\right)$ & 0.023 & 0.31 & 0.760 \\
\hline Ln (US-TARIFF $\left.F_{j t}\right)$ & -0.410 & $-1.88^{* * *}$ & 0.067 \\
\hline $\operatorname{Ln}\left(D_{I V E R_{i t}}\right)$ & 0.040 & 0.37 & 0.713 \\
\hline Ln (INPUTit_1) & 0.011 & $1.83^{* * *}$ & 0.074 \\
\hline $\operatorname{Ln}\left(I N S T Q_{i t}\right)$ & 0.055 & 0.43 & 0.671 \\
\hline $\begin{array}{l}\text { Number of observations }= \\
R^{2} \text { Within }=0.376 \\
R^{2} \text { Between }=0.761 \\
R^{2} \text { Overall }=0.422 \\
\text { Prob }>F=0.000\end{array}$ & 27 & & \\
\hline
\end{tabular}

*Significant at $1 \%,{ }^{* *}$ Significant at $5 \%$, and ***Significant at $10 \%$

From the estimation results in table 1 a $1 \%$ increase in exporting country's real GDP will lead to about a $1.3 \%$ increase in total agricultural export supply. The result also shows that coefficient of real GDP (lagged) is positive and statistically significant. As the estimated result indicates a1\% increase in real GDP (lagged), results in a $0.04 \%$ increase in the current total agricultural export. This result suggests that total agricultural export of a country at a point in time depends on not only real GDP of the country at that time but also the previous year's real GDP.

Turning to the impact of agricultural input use (which in this paper is captured by fertilizer consumption per hectare of arable land), we find some interesting result. The result suggests that a1 \%increase in the use of agricultural inputs in the previous period leads to a $0.006 \%$ increase in current total agricultural export. This result reiterates the importance of the use of agricultural inputs to enhance agricultural productivity and production of high value agricultural products, and hence increase total agricultural export of SSA countries. This positive relationship is also found in (Kandiero and Randa; 2004). Because of the fixed effects, the dummy variable, landlockedness, had to be omitted from the specification.

As the estimated result indicates the sign of the coefficient of FDI inflow as percentage of GDP is positive but statistically insignificant. This result supports the argument that FDI takes a longer time to impact on exports than other variables or FDI inflow to SSA countries have been driven by market seeking motives than exporting which has little contribution on total agricultural export supply to the international market.

The sign of the coefficient of real effective exchange rate is negative as expected. The insignificance of this variable reiterates that depreciating real effective exchange rate does not enhance the competitiveness of the agricultural export of SSA countries in the international market. Therefore, depreciation of exchange rate is little to do with improving SSA countries agricultural export. Moreover, the insignificant coefficient of institutional quality indicates that institutions affect trade through their impact on other variables (investment and productivity) that determines trade flows. Therefore, the effect of institutions on a sector where endowments determine comparative advantage (i.e. agricultural sector) is not considerable as compared to its effect on other sectors.

As far as the major external/demand side determinants is concerned, the estimation result indicates that the per capita GDP of US and import tariff imposed by US on agricultural commodities from SSA countries significantly affects agricultural export of the region. The result shows that a $1 \%$ increase in the per capita GDP of US, the major trading partner of SSA countries, increases the demand for agricultural products from SSA by $2.8 \%$ ( See Table 1).

The effect of import tariff imposed by US on agricultural products from SSA is negative and statistically significant which is in line with the theory. The estimated result indicates that a $1 \%$ increase in US tariff imposed on agricultural imports results in a $0.4 \%$ decrease in SSA countries agricultural export to US. This result indirectly questions the effectiveness of unilateral trade policy 
concession known as African Growth and Opportunity Act (AGOA) on U.S. imports from eligible Sub-Saharan African (SSA) countries in promoting the agricultural export of the eligible SSA countries. This finding is in line with the argument that in the US- SSA trade under AGOA trade policy concession is dominated by manufacturing, textile and petroleum products of which SSA countries do not have a comparative advantage.

\section{CONCLUSION}

The central question investigated in this paper is whether the supply side or the external/demand side factors significantly determine the agricultural export performance of SSA countries. To address this question we use the panel data consisting of 47 SSA countries over the period 2000-2008. The study uses secondary data collected mainly from WDI (2009), ADI (2010) and other sources. In this study total agricultural export (in million USD) is used as dependent variable and selected supply and demand side factors as independent/explanatory variables. Having discussed the various econometric issues that ought to be taken into consideration, the fixed effects model estimation results are preferred as the estimation technique yield consistent and efficient results. The empirical result obtained in this study indicates that the among the supply side factors, real GDP, real GDP(lagged) and lagged agricultural inputs are found to be statistically significant with their respective expected sign. The significant coefficient of real GDP, and real GDP(lagged) shows that high production capacity at a point in time and in the previous periods determines the export potential utilization and total supply of agricultural export for SSA countries.

Moreover, the positive and significant coefficient of lagged agricultural input use indicates the higher the use of agricultural input in one period may result in high agricultural production and more products will be exported in the following periods. The result also revealed that real effective exchange rate affects agricultural export of SSA positively but the insignificant coefficient indicates that depreciating the real exchange is little to do with enhancing agricultural export of SSA countries.

Regarding the demand side factors only per capita GDP of US, the major trading partner of SSA countries, positively and significantly affects the agricultural export of the region. This is in line with our expectation that the potential demand of trading partners will have positive effect on agricultural export of SSA countries. Moreover, the effect of agricultural import tariff imposed by US on SSA countries is found to be negative and significant which is in line with the prior expectation and the theory. This empirical finding suggests that exclusive market access provision of US for products from SSA countries under the unilateral trade policy concession known as African Growth and Opportunity Act (AGOA) does not enhance agricultural export of SSA countries.

Lastly, the empirical investigation in this study reiterates that both the supply and demand side factors are equally important in determining the total agricultural export of SSA countries. This study also finds that the contribution of foreign trade policy to the poor performance of SSA countries agricultural export is found to be significant.

\section{REFERENCES}

Ackah, C. and Morrissey,O (2005), “Trade Policy and Performance in Sub-Saharan Africa Since the 1980s",Credit Research Paper Vol.05, No.13,University of Nottingham, England.

Ades A. and R.D.Tella (1999), "Rents, Competition and Corruption", American Economic Review, Vol. 89,No.4, pp.982 - 993.,USA.

Agbeyegbe,T., Stotsky,J.G., and Asegedech,W(2006 ), "Trade Liberalization ,Exchange Rate Changes, and Tax Revenue in SubSaharan Africa", IMF Working Paper, IMF, Washington ,D.C.

Alemayehu Geda (1999), "Profile of Ethiopia's Export Performance", Proceedings of the Ethiopian Economic Association Annual Conference on the Ethiopian Economy, pp. 271-282.

Amin,A., Amunda,N., and Diop,B.(2007), "Can Africa Develop Through Trade in the Current Global Economy with Large Trading Blocks?",Paper presented with in the Conference on Sector-Led Growth in Africa and Implication for Development, Dakar, Senegal.

Babatunde, M.A. (2009), "Export Performance in Sub-Saharan Africa: An Explanation", Journal of Economic Theory, Vol.3, No.3, pp. 41-52., University of Ibadan, Nigeria.

Bacchetta,M.(2007), "Releasing Export Constraints: The Role of Governments", ERSD,WTO, available online at http:/ / www.aercafrica.org| documents| export-supplyworking-paper| Bachetta 18DB37.pdf accessed on 15/03/,2011.

Baltagi, Badi, H. (2005), “Econometric Analysis of panel Data", $3^{\text {rd }}$ edition. John Wiley \& Sons Ltd. West Sussex, England.

Beddassa,T. and Bichaka,T.(2007), " Assessing the Impact of Development Cooperation: the Case of African Growth and Opportunity Act (AGOA) and U.S. Imports from Sub- Saharan Africa", University of Minnesota-Duluth, Duluth, U.S.A.

Beshir Melcaw (2010), "The Determinants of Export of Primary Commodities in Sub-Saharan Africa: A Panel CoIntegration Approach", MSc thesis, Department of Economics, Addis Ababa University.

Biesebroeckvan,J. and Frazer G.(2007), “Trade Growth Under the African Growth Opportunity Act", NBER Working Paper No.13222, University of Toronto, Canada.

Biggs,T.(2007), “Assessing Export Supply Constraints: Methodology, Data, and Measurement", available online at http://www.aercafrica.org| documents| export_supply workingpapers| BiggsT- Assessing .pdf accessed on 15/03/2011.

Carmignani ,F. and Chowdhury, A.(2007), “The Role of Primary Commodities in Economic Development: Sub-Saharan Africa Versus the Rest of the World", Discussion paper, Geneva, Switzerland.

Chile, L., \& Talukder, D. (2014). The Paradox of Agricultural Trade Liberalization in Bangladesh and Tanzania.American Journal Of Trade And Policy, 1(1), 23-31. Retrieved fromhttp://journals.abc.us.org/index.php/ajtp/article/vie $\mathrm{w} / 1.3$

Clarke, G.R.G. (2005), "Beyond Tariffs and Quotas: Why Don't African Manufacturers Export More?", Policy Research Working Paper, Vol.4, No.3617, Washington, D.C. 
Cleaver, K. and Donovan, W.G.(1995), “ Agriculture, Poverty, and Policy Reform in Sub-Saharan Africa", World Bank Discussion Papers African Technical Department World Bank,Washington, D.C.

Cleaver, K.M. (1985), “The Impact of price and Exchange Rate Policies on Agriculture in Sub-Saharan Africa", World Bank Staff Working Papers, Washington, D.C.

Commission for Africa (2005),"Our Common Interest: Report of the Commission for Africa". Vol. 76, No. 4, pp. 446-450.

FAO (2006), "Food and Agriculture Organization of the United Nations Statistics Division", Rome, Italy

Fugazza,M.(2004), "Export Performance and Its Determinants: Supply and Demand Constraints", Policy Issues In International Trade and Commodities Study Series Vol.1,No.26, Geneva, Swaziland.

Ghura, D. and Grennes T. (1994), "The real Exchange Rate and Macroeconomic Performance in Sub-Saharan Africa," Journal of Development Economics, Vol. 12 No. 42., pp.155-174..

Helleiner, G.K. (2002), "Non- traditional export promotion in Africa - Experience and Issues" Helsinki: UNU/WIDER and London: Palgrave..

Herrman, R. (1997), “Agricultural Policies, Macroeconomic Policies, and Producer Price Incentives in Developing Countries: Cross-country Results for Major Crops", Journal of Developing Areas, Vol.3, No. 31, pp. 203-20.

Ignacio,L.L(2007) "Standards, Technical Regulations and Export Competitiveness: Focus on Sanitary and Phytosanitary Requirements", available online at http://www. aercafrica.org| documents| export_supply_working_papers| I gnacio_Implicati.pdf accessed on 22/03/2011

IMF (2002), “World Economic Outlook, October 2003”, IMF, Washington DC.

Islam, A. (2014). Agricultural Adaptation to Climate Change: Issues for Developing Countries. Global Disclosure Of Economics And Business, 2(2), 30-41. Retrieved from http:/ ischolar.in/index.php/GDEABC/article/view/54535

Kandiero, T. and Randa, J.(2004),"Agricultural Exports: Important Issues for Sub-Saharan Africa", African Development Review, Vol.16, No. 1, PP.1-35.

Kareem, I.O.(2009), "Trade Restrictions and Africa's Exports", Paper Presented at the Center for the Studies of African Economies conference, No.113675, University of Ibadan, Ibadan, Nigeria.

Kym, A. (2002), "Economy wide Dimensions of Trade Policy and Reform", in P. English,B.M. Hoekman and A. Mattoo (eds.), Development, Trade, and the WTO:AHandbook, World Bank, Washington, D.C.

Limao, N. and A. Venables (2000), "Infrastructure, Geographical Disadvantage and Transport Cost", World Bank Policy Research Paper, World Bank, Washington ,D.C.

Love, J. and Turner, E.(2001), "Exports, Domestic Policy and World Markets: A Panel Study", Journal of International Development .vol.13:No. 5, pp.615-627, UK.

Manduna (2005),"Assessing the Causes of Sub-Saharan Africa's Declining Exports and Addressing Supply Side Constraints", tralac Working Paper, Vol. 1, No.2,

Mbekeani, Kennedy K. (2007), “The Role of Infrastructure in Determining Export Competitiveness", available online at http:/ / www.aerdafrica.org, accessed on 16/03/2011.

Méon, P.,and Sekkat, K. (2006), "Institutional Quality and Trade: Which Institutions? Which Trade?", Document De Travail Working Paper No.06, University of Brussels, Belgium.

Morrissey, O. and Mold, A. (2010), "Explaining Africa's Export Performance - Taking a New Look". Available online at http://www.gtap.agecon.purdue.edul resources| download| 2673.pdf accessed on 12/03/2011
Pavia,C.(2008), "Assessing Protectionism and Subsidies in Agriculture-A gravity Approach", Journal of International Development Vol.20 No.,pp.628-640, California State University.

Prizzon,A. and Mold, A.(2010), "Fragile States ,Commodity Booms and Export Performance: An Analysis of the SubSaharan Africa Case", EU Working Papers ,Italy.

Raihana, B. (2012). Trend in Productivity Research in Bangladesh Agriculture: A Review of Selected Articles. Asian Business Review, 1(1), 1-4. Retrieved from http://ischolar.in/index.php/ABRABC/article/view/54419

Redding,S. and Venables,A.J. (2003), “Geography and Export Performance: External Market Access and Internal Supply Capacity", NBER Working Paper ,UK.

Rodrik,D.(1997), "Trade Policy and Economic Performance in Sub-Saharan Africa", University of Harvard, England.

Romalis, John (2003), “Would Rich Country Trade Preferences Help Poor Countries Grow? Evidence from the Generalized System of Preferences," mimeo, University of Chicago

Sacks, J. and Warner, A (1995), "Economic reform and the process of global integration", Working papers on economic activity, World Bank, Washington, D.C.

Schiff, M. and A. Valdes (1992),"The Plundering of Agriculture in Developing Countries", World Bank, Washington, D.C.

Staatz,J. and Dembele ,N.N.(2007), "Agriculture for Development in Sub-Saharan Africa"Background paper for WDR report, No.41378, University of Michigan.

Wang, Zhen Kun and Winters,L. Alan (1998),“'Africa's Role in Multilateral Trade Negotiations: Past and Future", Journal of African Economies, Supplement, Vol. 23, No. 7, pp. 1-33, World Bank, Washington, D.C.

Wilson, J. and T. Otsuki (2004) "Standards and Technical Regulations and Firms in Developing Countries: New Evidence from a World Bank Technical Barriers to Trade Survey", Draft, World Bank, Washington, D.C.

Wood, A. (2002), “Could Africa Be Like America?" A paper presented at the Annual Bank Conference on Development Economics, Washington, D.C.

World Bank (2005c) “World Development Indicators 2005", World Bank Washington, D.C.

World Bank (2006b), “Development Data Platform (Ddp)”, World Bank, Washington, D.C.

World Bank (2007), “World Development Indicators", World Bank, Washington, D.C. 
ANNEXES

\section{ANNEX 1: Hausman Specification Test}

. hausman fe re

\begin{tabular}{|c|c|c|c|c|}
\hline & \multicolumn{2}{|c|}{ Coefficients -} & \multirow[b]{2}{*}{$\begin{array}{c}(\mathbf{b}-\mathbf{B}) \\
\text { Difference }\end{array}$} & \multirow[b]{2}{*}{$\begin{array}{c}\text { sqrt (diag(V_b-V_B })) \\
\text { S.E. }\end{array}$} \\
\hline & $\begin{array}{l}\text { (b) } \\
\text { fe }\end{array}$ & $\begin{array}{l}\text { (B) } \\
\text { re }\end{array}$ & & \\
\hline Inrgdpi & .0348374 & .1083605 & -.0735231 & .0067423 \\
\hline Ingdpcapusi & 4.072927 & 3.854378 & .2185488 & \\
\hline $\begin{array}{l}\text { Inreeri } \\
\text { Inopeni }\end{array}$ & -.0846599 & -.0731104 & -.0115496 & .0060178 \\
\hline Inopeni & .0100125 & -.04177 & .0517825 & \\
\hline Inus_tariffi & -.9610931 & -.9287945 & -.0322986 & . \\
\hline Infdipergdpi & .029582 & .0216926 & .0078895 & \\
\hline Indiveri & -.0209533 & .0440973 & -.0650506 & .0223252 \\
\hline Ininputsi & -.0016887 & .0009934 & -.0026821 & \\
\hline Ininstq & .0885952 & .0690024 & .0195927 & .0054575 \\
\hline landlock & .5774662 & .1013775 & .4760887 & .2271755 \\
\hline
\end{tabular}

$b=$ consistent under Ho and Ha; obtained from xtreg
B = inconsistent under Ha, efficient under Ho; obtained from xtreg

Test: Ho: difference in coefficients not systematic

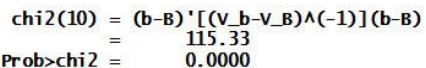

( $\_\_b-v \_$B is not positive definite)

\section{ANNEX 2: Durbin-WU-Hausman Endogenity Test}

- ivregress 2sls 1ntaet Ingdpcapusi Inreeri Inopeni Inus_tariffi Infdipergdpi Indiveri 1ninputsi 1ninst landlock (1nrgdp= dl.1nrgdp)

Instrumental variables (2SLS) regression

$\begin{array}{rr}\text { Number of obs }= & 236 \\ \text { wald chi2 }(10) & =109.71\end{array}$ rob $>$ chi2 $=0.000$ R-squared $=0.371$

\begin{tabular}{|c|c|c|c|c|c|c|}
\hline Tntaet & Coef. & Std. Err. & $z$ & $P>|z|$ & [95\% Conf. & Interval] \\
\hline 1nrgdpi & .132978 & 2777186 & 0.48 & 0.632 & -.4113405 & 6772965 \\
\hline $\begin{array}{l}\text { 1ngdpcapusi } \\
\text { Tnreeri }\end{array}$ & $\begin{array}{r}7.4602944 \\
-.0429376\end{array}$ & 6.014591 & $\begin{array}{r}1.24 \\
-0.50\end{array}$ & $\begin{array}{l}0.215 \\
0.620\end{array}$ & -4.328087 & 19.24868 \\
\hline $\begin{array}{l}\text { Inr eer1 } \\
\text { Inopeni }\end{array}$ & -1.340327 & $\begin{array}{l}.08654456 \\
.5473209\end{array}$ & $\begin{array}{l}-0.50 \\
-2.45\end{array}$ & 0.014 & -2.413057 & $\begin{array}{r}-1266886 \\
-.2675979\end{array}$ \\
\hline Tnus_tariffi & -1.307486 & .6192307 & -2.11 & & -2.521156 & -.0938162 \\
\hline Infdipergdpi & -.0337547 & .0758013 & -0.45 & 0. & -.1823224 & .1148131 \\
\hline Indiveri & .229 & .135 & 1.65 & 0.1 & -.0436917 & .503059 \\
\hline Ininputsi & .252 & .067 & 3.76 & 0.0 & .12 & .3846907 \\
\hline Ininst & i.o & .653 & 1.59 & 0.1 & -.2 & 2.31 \\
\hline Tand lock & .086 & .2877555 & 0.30 & 0. & -.47 & .6506537 \\
\hline _cons & -54 . & 61.65616 & -0.88 & 0.378 & -175.1843 & 66.50345 \\
\hline
\end{tabular}

end of do-file

. do "C:\Users\uae\AppData\Local\Temp\STD00000000. tmp"

- estat endogenous

Tests of endogeneity
Ho: variables are exogenous

tho: variables are exagenous

Durbin (score) chiz(1)
Wu-Hausman F(1,224)

$\begin{array}{ll}=3.99152 & (p=0.0457) \\ =3.85374 & (p=0.0509)\end{array}$

ANNEX 3: Heteroskedasticity Test

\begin{tabular}{|c|c|c|c|c|c|c|}
\hline \multicolumn{6}{|c|}{$\begin{array}{c}\text { - reg ei2 lnrqdpi Inqdpcapusi Inqdpcapeui Inreeri Ininfrai Inopeni } \\
\text { Infdipergdpi Inus_tariffi Ineu_tar iffi Indiveri Ininputs }\end{array}$} & Ininst \\
\hline $\begin{array}{r}\text { i landlock } \\
\text { Source }\end{array}$ & SS & df & MS & & \multirow{3}{*}{$\begin{array}{l}\text { Number of obs } \\
\text { F( 13, 304) } \\
\text { Prob > F } \\
\text { R-squared } \\
\text { Adj R-squared } \\
\text { Root MSE }\end{array}$} & \multirow{3}{*}{$\begin{array}{lr}= & 318 \\
= & 95561.11 \\
= & 0.0000 \\
= & 0.9998 \\
= & 0.9997 \\
= & .22496\end{array}$} \\
\hline $\begin{array}{r}\text { Model } \\
\text { Residual }\end{array}$ & $\begin{array}{l}62870.9185 \\
15.3850485\end{array}$ & $\begin{array}{rr}13 & 48 \\
304 & .05\end{array}$ & $\begin{array}{ll}36.2245 \\
0608712\end{array}$ & & & \\
\hline Total & 62886.3036 & $317 \quad 198$ & 379507 & & & \\
\hline ei2 & Coef. & Std. Err. & $t$ & $P>|t|$ & nf. & Interval] \\
\hline & & & & & & \\
\hline & & & & & & \\
\hline & & & & & & 67 \\
\hline & & .00 & -45 & & & \\
\hline & & & & & & \\
\hline & & & & & & \\
\hline & & & -12 & & & 853 \\
\hline & & & & & & 504 \\
\hline & & & & & & -5 . \\
\hline & & & & & & \\
\hline & & & & & & \\
\hline & & & & & & \\
\hline & -3066.375 & .90565 & -220. & & -309 & -3039.01 \\
\hline
\end{tabular}

$\mathrm{H}_{0}$ : Homoskastic residuals; Ha: Heteroskedasticity

Test statistic: $\mathrm{R}^{2}(\mathrm{~N}(\mathrm{~T}-1))=0.998(318(13-1))=3804.368$

Tabulated value $\chi^{2} 13,0.950=22.36$

As the test statistic is greater than the tabulated value we reject the null hypothesis of homoskedasticity.
ANNEX 4: Panel Unit -Root or Stationarity Test

- xtunitroot 11c Ingdpcapusi

Levin-Lin-Chu unit-root test for Ingdpcapusi

$\begin{array}{lll}\text { Ho: Panels contain unit roots } & \text { Number of panels }= & 47 \\ \text { Ha: Panels are stationary } & \text { Number of periods }= & 9\end{array}$

AR parameter: Common

Asymptotics: $\mathrm{N} / \mathrm{T} \rightarrow \mathrm{O}$

Panel mears: Included

ADF regressions: 1 lag

LR variance: Bartlett kerne1, 6.00 lags average (chosen by LLC)

\begin{tabular}{lll}
\hline & Statistic & p-value \\
\hline $\begin{array}{l}\text { Unadjusted } t \\
\text { Adjusted } t^{*}\end{array}$ & -14.9636 & 0.0000 \\
\hline
\end{tabular}

- xtunitroot 11c 1nreeri, trend

Levin-Lin-Chu unit-root test for 1nreeri

Ho: Panels contain unit roots

$\begin{array}{lr}\text { Number of panels }= & 47 \\ \text { Number of periods }= & 9\end{array}$

AR parameter: Common

Asymptotics: $\mathrm{N} / \mathrm{T} \rightarrow \mathrm{O}$

Panel means: Included
Time trend: Included

ADF regressions: 1 lag
LR variance:

\begin{tabular}{|c|c|c|}
\hline & Statistic & p-value \\
\hline $\begin{array}{l}\text { Unadjusted } t \\
\text { Adjusted } t^{t}\end{array}$ & $\begin{array}{l}-18.2173 \\
-10.9310\end{array}$ & 0.0000 \\
\hline
\end{tabular}

Levin-Lin-Chu unit-root test for Inopeni

Ho: Panels contain unit roots
Ha: Panels are stationary

$\begin{array}{lr}\text { Number of panels }= & 47 \\ \text { Number of periods }= & 9\end{array}$

AR parameter: Common

Asymptotics: $\mathrm{N} / \mathrm{T} \rightarrow \mathrm{O}$

Panel means: Included
Time trend: Included

ADF regressions: 1 lag
LR variance:

LR variance:

$\begin{array}{lll}\text { Unadjusted } t & -29.1493 & \\ \text { Adjusted } t^{*} & -23.5545 & 0.0000\end{array}$

xtunitroot 11c Ininst, trend

Levin-Lin-Chu unit-root test for Ininst

Ho: Panels contain unit roots

AR parameter: Common

$\begin{array}{lr}\text { Number of panels }= & 47 \\ \text { Number of periods }= & 9\end{array}$

AR parameter: Common

Asymptotics: $\mathrm{N} / \mathrm{T} \rightarrow \mathrm{O}$

Levin-Lin-Chu unit-root test for Intaet

Ho: Panels contain unit roots
Ha: Panels are stationary

$\begin{array}{lr}\text { Number of panels }= & 47 \\ \text { Number of periods }= & 9\end{array}$

AR parameter: Common

Asymptotics: N/T $\rightarrow 0$

AR parameter: Common
Pane1 means: Included
Time trend: Included

ADF regressions: 1 lag
LR variance:

\begin{tabular}{lll}
\hline & Statistic & p-value \\
\hline Unadjusted $t$ & -25.8225 & 0.0000 \\
Adjusted $t *$ & -18.0503 & 0.000 \\
\hline
\end{tabular}

(47) missing values generated) trend

Levin-Lin-Chu unit-root test for laglnrgdpi

Ho: Panels contain unit roots
Ha: Panels are stationary

$\begin{array}{ll}\text { Number of panels }= & 47 \\ \text { Number of periods }= & 8\end{array}$

AR parameter: Common

Pane1 means: Included

Asymptotics : N/T $\rightarrow 0$

ADF regressions: 1 lag
LR variance:

\begin{tabular}{lll} 
LR variance: & Bartlett kernel, 6.00 lags average (chosen by LLC) \\
\hline & Statistic & p-value \\
\hline Unadjusted $t$ & -48.1900 & \\
Adjusted $t^{*}$ & -43.4274 & 0.0000
\end{tabular}

- xtunitroot 11c Inrgdpi, trend

Levin-Lin-Chu unit-root test for Inrgdpi

Ho: Panels contain unit roots
Ha: Panels are stationary

AR parameter: Common
Pane1 means:
Time trend: Included

$\begin{array}{lr}\text { Number of panels }= & 47 \\ \text { Number of periods }= & 9\end{array}$

ADF regressions: 1 lag
LR variance:

\begin{tabular}{lll}
\hline & Statistic & p-value \\
\hline $\begin{array}{l}\text { Unadjusted } t \\
\text { Adjusted } t *\end{array}$ & -37.4566 & 0.0000 \\
\hline
\end{tabular}

-0 - 